\title{
Reaction of advanced lines of triticale to karnal bunt (Tilletia indica)
}

DOI: $10.46932 / s f j d v 2 n 2-036$

Received in: january 1st, 2020

Accepted in: March 30th, 2020

\section{Guillermo Fuentes-Dávila}

Ph.D. in Plant Pathology

INIFAP, Campo Experimental Valle del Yaqui,Apdo. Postal 155, km 12 Norman E. Borlaug, entre 800 y 900, Valle del Yaqui, Cd. Obregón, Sonora, México CP 85000.

E-mail: fuentes.davila@gmail.com

\section{Ivón Alejandra Rosas-Jáuregui}

M.S. in Plant Pathology

INIFAP, Campo Experimental Valle del Yaqui,Apdo. Postal 155, km 12 Norman E. Borlaug, entre 800 y 900, Valle del Yaqui, Cd. Obregón, Sonora, México CP 85000.

E-mail: ivonn1590@ hotmail.com

\section{Carlos Antonio Ayón-Ibarra}

B.S. in Biosystems

CIMMYT, Int., km 12 Norman E. Borlaug, entre 800 y 900, Valle del Yaqui, Cd. Obregón, Sonora,

México CP 85000.

E-mail: carlos_21026@ hotmail.com

\section{José Luis Félix-Fuentes}

M.S. in Natural Resources

INIFAP, Campo Experimental Valle del Yaqui,Apdo. Postal 155, km 12 Norman E. Borlaug, entre 800 y 900, Valle del Yaqui, Cd. Obregón, Sonora, México CP 85000.

E-mail: j_luis_ff@yahoo.com.mx

\section{Pedro Félix-Valencia}

M.S. in Botany

INIFAP, Campo Experimental Valle del Yaqui,Apdo. Postal 155, km 12 Norman E. Borlaug, entre 800 y 900, Valle del Yaqui, Cd. Obregón, Sonora, México CP 85000.

E-mail: pedrofelixvalencia@gmail.com

\begin{abstract}
Twenty advanced lines of triticale were evaluated for resistance to karnal bunt during the 2014-2015 crop season, at the Norman E. Borlaug Experimental Station. The sowing dates were November 19 and 29, 2014. One $\mathrm{mL}$ of an allantoid sporidial suspension $(10,000 / \mathrm{mL})$ was injected during the boot stage of ten spikes per line. A mist-irrigation system was used to provide high humidity in the experimental area. Harvesting and threshing were done manually, and the counting of infected and healthy grains was perfomed by visual inspection. The range of infection for the first sowing date was $0-2.4 \%$, with an average of 0.3 , and for the second $0-1.4 \%$, with an average of 0.4 . Five lines did not show any infected grains in both dates and the rest was in the $0.1-2.5 \%$ infection category. The average of infection of the
\end{abstract}


susceptible check during the period of inoculation of this group of lines was $86.6 \%$. The highest average percentage of infection of both dates were shown by lines: TURACO/CENT.SARDEV/7/LIRON_2/5/DISB5/3/SPHD/ PVN//YOGUI_6/4/KER_3/6/BULL_10/MANATI_1/8/LIRON_2/5/DISB5/3/SPHD/PVN// YOGUI_6/4/KER_3/6/BULL_10/MANATI_1/9/BICEN (CTSS08Y00035S-099Y-026M-19Y-099M2Y-2BMX-4Y) with 1.6 and POPP1_2/CAAL//THELIN\#2/5/PRESTO//2*TESMO_1/ MUSX603/4/ARDI_1/TOPO1419//ERIZO_9/3/SUSI_2/6/ARDI/GNU//2*FAHAD_1/4/BULL_ 10/MANATI_1/3/ELK54/ BUF_2//NIMIR_3 with 1.3\%. These lines also showed the highest percentage of infection in the first date with 1.8 and $2.4 \%$, respectively.

Keywords: Tilletia indica, triticale, Triticosecale, Karnal bunt.

\section{INTRODUCTION}

Karnal bunt caused by the fungus Tilletia indica Mitra [syn. Neovossia indica (Mitra) Mundkur] occurs in nature on bread wheat (Triticum aestivum; MITRA 1931), durum wheat (T.turgidum), and triticale (X Triticosecale; AGARWAL et al., 1977). Infected grains are generally partially affected (Fig. 1) and is not common to find completely infected ones (MITRA, 1935; BEDI et al., 1949; CHONA et al., 1961).

This disease was first reported from India (MITRA, 1931); then from Mexico (DURAN, 1972), Pakistan (MUNJAL, 1975), Nepal (SINGH et al., 1989), Brazil, (DA LUZ et al., 1993), The United States (APHIS, 1996), Iran (TORARBI et al., 1996), The Republic of South Africa (CROUS et al., 2001), and Afghanistan (CIMMYT, 2011).

Control of this organism is difficult since its teliospores can stand physical and chemical factors (SMILANICK et al., 1988). Chemical control can be accomplished by fungicide applications during the flowering stage of the wheat plant (SALAZAR-HUERTA et al., 1997;

Figure. 1. Symptoms of karnal bunt on triticale grain and teliospores of Tilletia indica.

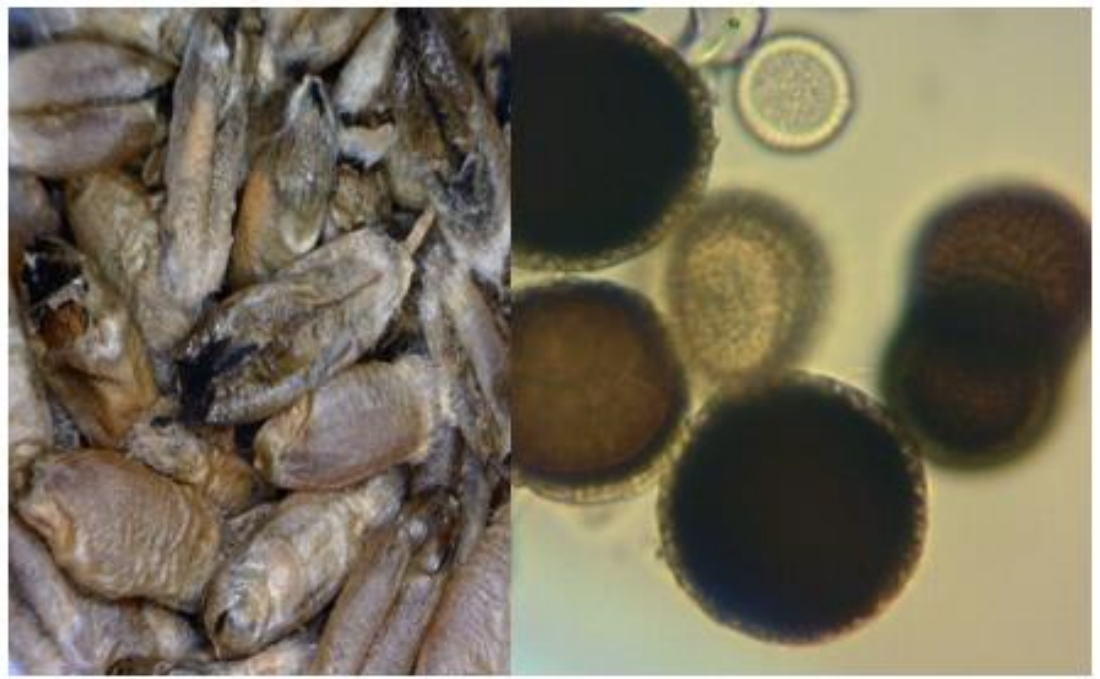


FUENTES-DÁVILA, 2007; FUENTES-DÁVILA et al., 2005, 2016, 2018); however, when quarantine regulations do not allow tolerance levels for seed production (SARH, 1987), this measure is not economically feasible for commercial implementation. The use of resistant wheat cultivars to karnal bunt is the most appropriate control measure, which would also reduce the possibilities of introduction of the disease to karnal bunt-free areas. Since the 1940's several Triticum species have been evaluated for karnal bunt resistance (BEDI et al., 1949; SINGH et al., 1988). Reports about the resistance and immunity of cultivars and advanced lines of triticale (x Triticosecale Wittmack) under artificial inoculation date since the 1980's (METZGER, 1984); therefore, the objective of this work was to determine the reaction of advanced lines of triticale to karnal bunt, artificially inoculated in the field.

\section{MATERIALS AND METHODS}

Twenty advanced lines of triticale generated by the collaborative project between the International Maize and Wheat Improvement Center (CIMMYT) and the National Institute for Forestry, Agriculture, and Livestock Research of Mexico (INIFAP), were evaluated for karnal bunt resistance during the crop season Fall-Winter 2014-2015 at the Norman E. Borlaug Experimental Station of INIFAP, located in block 910 of the Yaqui Valley in the State of Sonora (27 $22^{\prime} 3.01^{\prime \prime} \mathrm{N}$ and $109^{\circ} 55^{\prime} 40.22^{\prime \prime} \mathrm{W}$; 37 masl), in a clay soil with a $\mathrm{pH}$ of 7.8. Sowing dates were November 19 and 29, 2014, using approximately $8 \mathrm{~g}$ of seed for a row $0.7 \mathrm{~m}$ long in a bed with two rows and without replications.

For inoculum preparation (FUENTES-DÁVILA et al., 1993), teliospores were obtained from infected grains, which were stirred in a tween $20+$ water solution in test tubes, then, they were sieved through a $60 \mu \mathrm{m}$ mesh to remove large particles and were maintained in the solution for $24 \mathrm{~h}$. Thereafter, teliospores were precipitated by centrifugation at 3,000 rpm, decanted, sodium hypochlorite $0.6 \%$ was placed in the tubes to disinfest teliospores while centrifuging at 3,000 rpm for two minutes, decanted, sterile distilled water was added to the tubes to remove the excess of sodium hypochlorite while centrifuging again. Teliospores were plated on $2 \%$ water agar under aseptic conditions using a sterile syringe and incubated at $18-22^{\circ} \mathrm{C}$ until germination was detected. Pieces of water-agar where teliospores had germinated, were inverted on the lids of Petri plates with potato-dextrose-agar to estimulate the production of secondary sporidia. After nine days of growth, sterile water was added to the plates with fungal colonies developing, then they were scrapped with a flamed spatula and the suspension was transferred to fresh PDA plates to increase the inoculum. Once the plates were covered with fungal growth, pieces of PDA-fungus were cut and placed inverted on the lids of sterile glass Petri plates, and sterile water was placed at the bottom of the plates from which secondary sporidia were collected every day, counted with a hemacytometer and the concentration adjusted to 10,000 por $\mathrm{mL}$. 
Inoculations were done by injecting with a hypodermic syringe $1 \mathrm{~mL}$ of the sporidial suspension $(10,000 / \mathrm{mL})$ during the boot stage of the wheat plant (phenological stage 49, ZADOKS et al., 1974) in ten spikes per line (Fig. 2). The susceptible line KB SUS 1 generated in our program, was used as a susceptible reference during the entire work. An automated mist irrigation system was used five times a day during 20 min each time, in order to maintain the experimental area with high humidty, and a net system was put in place to avoid damage by birds (Fig. 3). Harvesting and threshing were done manually, and the counting of healthy and infected grains were done by visual inspection.

\section{RESULTS AND DISCUSSION}

The range of the percentage of infection of the advanced lines in the first date was 0 to $2.4 \%$, with an average of 0.3 ; ten lines did not show infected grains. The range of the percentage of infection for the second date was 0 to $1.4 \%$, with an average of 0.4 , eleven lines did not show infected grains. Five lines did not show infected grains in both dates (Table 1), and the rest of lines were in the $0.1-2.5 \%$ infection category.

Figure 2. Inoculation of triticale advanced lines with Tilletia indica during the boot stage.

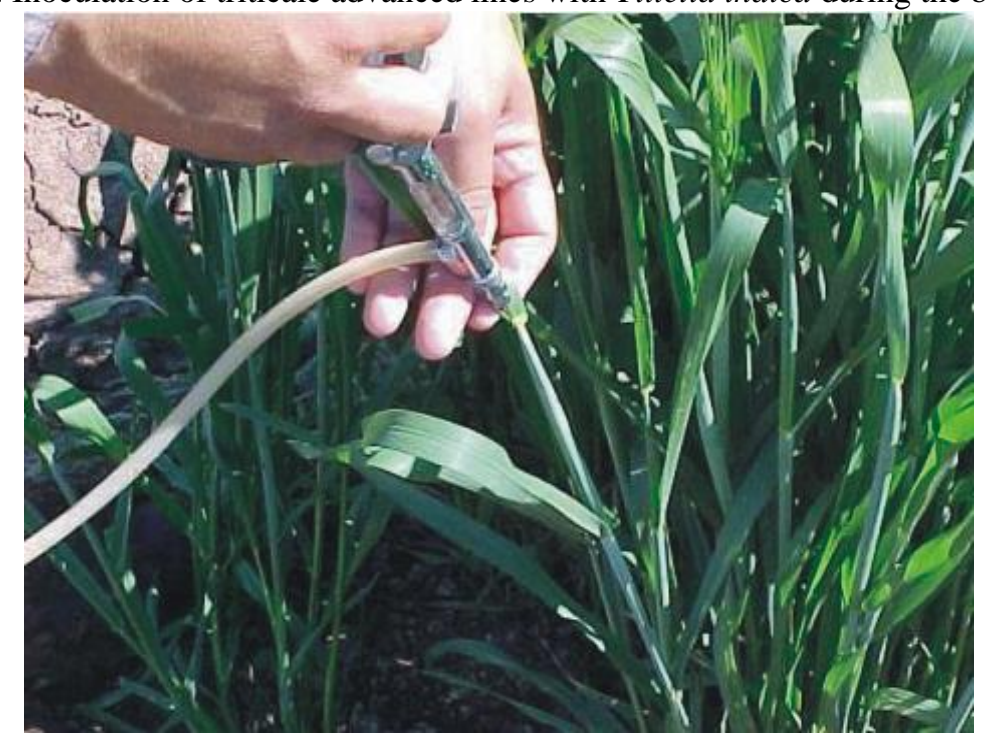


Figure 3. Mist irrigation system and antibird net.

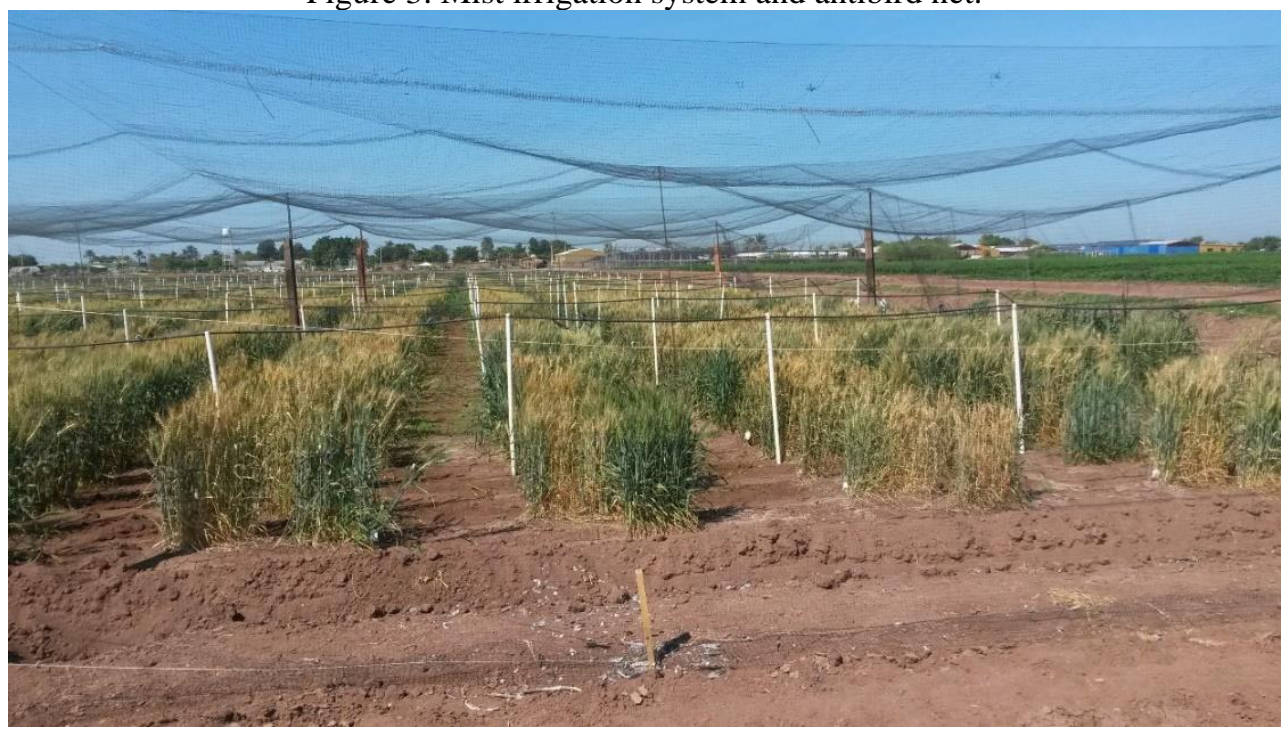

Table 1. Advanced lines of triticale that did not show any infected grains, after artificial field inoculation with karnal bunt (Tilletia indica) in two sowing dates, during the crop season 2014-2015, at the Norman E. Borlaug Experimental Station in the Yaqui Valley, Sonora, Mexico.

\begin{tabular}{cl}
\hline No. & \multicolumn{1}{c}{ Pedigree and history selection } \\
\hline 1 & BAT*2/BCN//CAAL/3/ERIZO_7/BAGAL_2//FARAS_1/8/GAUR_2/HARE_3//JLO97/CIVET/5/DISB5/3/S \\
& PHD/PVN//YOGUI_6/4/KER_3/6/150.83//2*TESMO_1/MUSX603/7/GAUR_2 /HARE_3//JLO97/CIVET \\
& CTSS04B00008S-020Y-24M-2Y-0M-2Y-0M \\
2 & NILEX/3/BULL_10/MANATI_1//FARAS/CMH84.4414/6/HX87-244/HX87-255/5/PRESTO// \\
& 2*TESMO_1/MUSX603/4/ARDI_1/TOPO1419//ERIZO_9/3/SUSI_2 \\
& CTSS08Y00155T-099Y-016M-18Y-099M-6Y-1BMX-4Y \\
3 & 95T159/4/T1502_WG/MOLOC_4//RHINO_3/BULL_1-1/3/POLLMER_3/FOCA_2-1/5/ \\
& CAAL/3/T1494_WG//ERIZO_10/2*BULL_1-1 \\
& CTSS08Y00168T-099Y-024M-5Y-099M-1Y-4BMX-1Y \\
& TURACO/CENT.SARDEV/7/LIRON_2/5/DISB5/3/SPHD/PVN//YOGUI_6/4/KER_3/6/ \\
& BULL_10/MANATI_1/8/LIRON_2/5/DISB5/3/SPHD/PVN//YOGUI_6/4/KER_3/6/BULL_ \\
& 10/MANATI_1/9/BICEN \\
& CTSS08Y00035S-099Y-026M-5Y-099M-17Y-1BMX-4Y \\
& TICKIT/TREAT/7/LIRON_2/5/DISB5/3/SPHD/PVN//YOGUI_6/4/KER_3/6/BULL_10/ \\
& MANATI_1/8/PRESTO//2*TESMO_1/MUSX603/4/ARDI_1/TOPO1419//ERIZO_9/3/ \\
& SUSI_2/5/AR/SNP6//TARASCA 87_2/C,S10/3/PORSAS_4-1/4/CHACAL_3-2 \\
& CTSS08Y00130S-099Y-037M-9Y-099M-5Y-3BMX-3Y
\end{tabular}

The average of the three highest percentages of infection of the susceptible check during the course of the work where other wheat nurseries were also evaluated was 98.6\% (FUENTES-DÁVILA et al., 2017), but during the period of inoculation for the first date of triticale lines (February 2, 5, and 12, 2015), the average of infection of the susceptible check was $87.8 \%$, and during the period of inoculation for the second date (February 12 and 18, 2015), the average infection was 85.9\%, and 86.6\% for the whole period. Lines that showed the highest average percentage of infection in both dates were: TURACO/CENT.SARDEV/7/LIRON_2/5/DISB5/3/ 
//YOGUI_6/4/KER_3/6/BULL_10/ MANATI_1/9/BICEN (line 12) (CTSS08Y00035S-099Y-026M19Y-099M-2Y-2BMX-4Y) with 1.6 and POPP1_2/CAAL//THELIN\#2/5/PRESTO//2* TESMO_1/MUSX603/4/ARDI_1/TOPO1419//ERIZO_9/3/SUSI_2/6/ARDI/GNU//2*FAHAD _1/4/BULL_10/MANATI_1/3/ELK54/ BUF_2// NIMIR_3 (line 16) with 1.3\% (Graph 1). These lines also showed the highest percentage of infection in the first date with 1.8 and $2.4 \%$, respectively.

Graph 1. Average percentage of infection with karnal bunt in two sowing dates of 20 advanced lines of triticale, evaluated under artificial field inoculation during the crop season 2014-2015, at the Norman E. Borlaug Experimental Station in the Yaqui Valley, Sonora, Mexico.

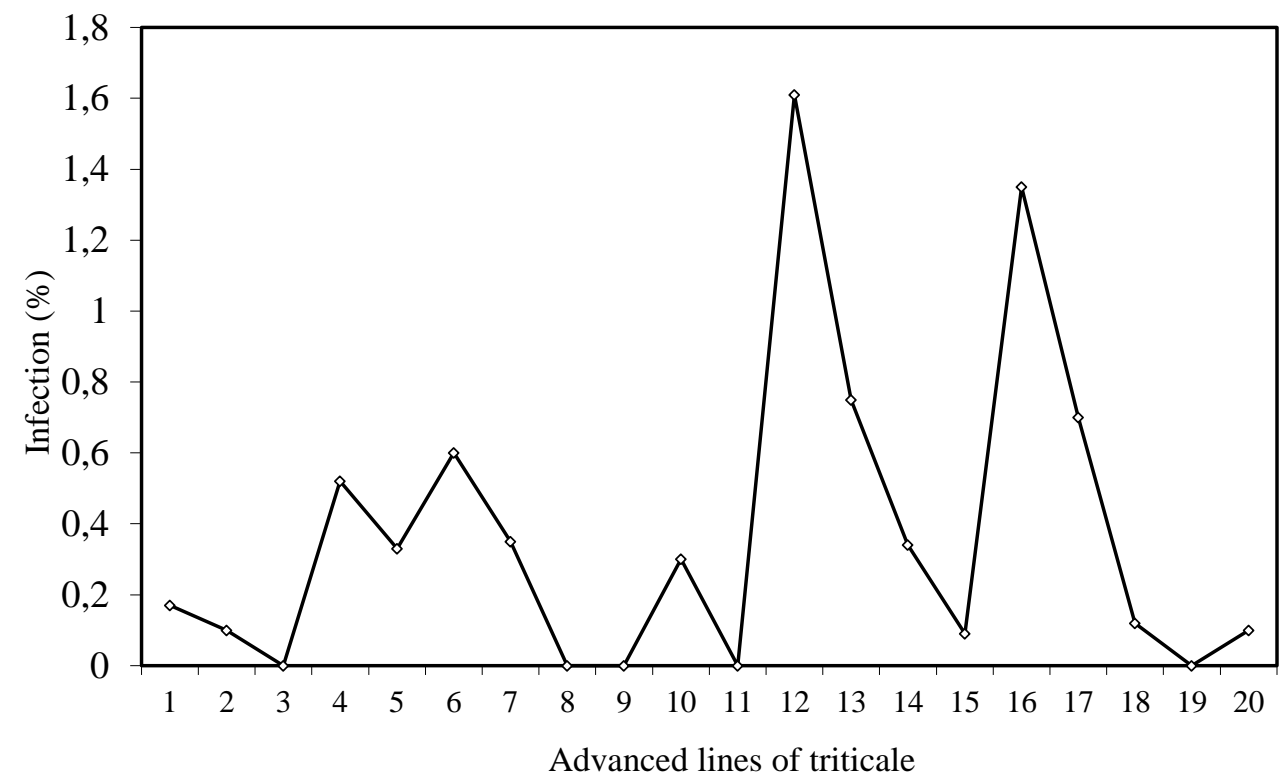

Since the initial artificial field inoculations with karnal bunt in northwest Mexico of a large number of experimental triticale and wheat lines, as well as a diverse group of grasses, resistance of most triticale lines and immunity in some other lines have been reported (METZGER, 1984). Fuentes-Dávila et al. (2012a) also reported that out of 20 triticale experimental lines evaluated during the crop season 2007 2008, nine did not show any infected grains, while in 2008-2009 19 out from another group of 20 (FUENTES-DÁVILA et al., 2012b); during the crop season 2009-2010 eleven did not show any infected grains (FUENTES-DÁVILA et al., 2013a), during 2010-2011 there were 5 (FUENTES-DÁVILA et al., 2013b), and during 2011-2012 there were 8 (FUENTES-DÁVILA et al., 2014).

Wheat lines that fall into the $0.1-5.0 \%$ infection category are considered as resistant to karnal bunt (FUENTES-DÁVILA and RAJARAM, 1994) and have a high potential to be used as progenitors in a breeding program, but in the case of triticale not only the resistance is detected, whether genetic or field resistance or both, but also an immunity reaction in some experimental lines. 
However, it it important that advanced triticale experimental lines should be evaluated in a consistent manner in order to assure that the low levels of infection and the immunity reaction are are not due to escapes to the disease. In this evaluation all the lines evaluated are considered as resistant to karnal bunt. These results show a high level of resistance in the newly triticale experimental lines generated by CIMMYT and INIFAP, and although this cereal is not contemplated within the mexican federal government programs so far, it represents and excellent option for agricultural farmers and the livestock sector, with the objectives of grain production and grazing in the areas affected by karnal bunt.

\section{CONCLUSIONS}

The advanced lines of triticale BAT*2/BCN//CAAL/3/ERIZO_7/BAGAL_2//FARAS_1/8/ GAUR_2/HARE_3//JLO97/CIVET/5/DISB5/3/SPHD/PVN//YOGUI_6/4/KER_3/6/150.83//2* TESMO_1/MUSX603/7/GAUR_2/HARE_3//JLO97/CIVET, NILEX/3/BULL_10/MANATI_ 1//FARAS/CMH84.4414/6/HX87-244/HX87-255/5/PRESTO//2*TESMO_1/MUSX603/4/ARDI _1/TOPO1419//ERIZO_9/3/SUSI_2, 95T159/4/T1502_WG/MOLOC_4//RHINO_3/BULL_11/3/POLLMER_3/FOCA_2-1/5/CAAL/3/T1494_WG//ERIZO_10/2*BULL_1-1, TURACO/ CENT.SARDEV/7/LIRON_2/5/DISB5/3/SPHD/PVN//YOGUI_6/4/KER_3/6/BULL_10/ MANATI_1/8/LIRON_2/5/DISB5/3/SPHD/PVN//YOGUI_6/4/KER_3/6/BULL_10/MANATI_ 1/9/BICEN, and TICKIT/TREAT/7/LIRON_2/5/DISB5/3/SPHD/PVN//YOGUI_6/4/KER_3/6/ BULL_10/MANATI_1/8/PRESTO//2*TESMO_1/MUSX603/4/ARDI_1/TOPO1419//ERIZO_9 /3/SUSI_2/5/AR/SNP6//TARASCA87_2/C,S10/3/PORSAS_4-1/4/CHACAL_3-2, did not show any infected grains in both dates of evaluation. 


\section{REFERENCES}

AGARWAL, V. K.; VERMA, H. S.; and KHETARPAL, R. K. (1977). Occurrence of partial bunt on triticale. Plant Protection Bulletin, 25, 210-211.

ANIMAL AND PLANT HEALTH INSPECTION SERVICE (APHIS). (1996). Karnal bunt: situation report update (March 29). USDA-APHIS, Plant Protection and Quarantine (http://www.aphis.usda.gov/oa/bunt).

BEDI, S. K. S.; SIKKA, M. R.; and MUNDKUR, B. B. (1949). Transmission of wheat bunt due to Neovossia indica (Mitra) Mundkur. Indian Phytopathology, 2, 20-26.

CHONA, B. L.; MUNJAL, R. L.; and ADLAKHA, K. L. (1961). A method for screening wheat plants for resistance to Neovossia indica. Indian Phytopathology, 14, 99-101.

CENTRO INTERNACIONAL DE MEJORAMIENTO DE MAÍZ Y TRIGO (CIMMYT). (2011). Training to beat karnal bunt in Afghanistan. http://blog.cimmyt.org/ tag/karnal-bunt/. Accessed March 1, 2014.

CROUS, P. W.; VAN JAARSVELD, A. B.; CASTLEBURY, L. A.; CARRIS, L. M.; FREDERICK, R. D.; and PRETORIUS, Z. A. (2001). Karnal bunt of wheat newly reported from the African continent. Plant Disease, 85, 561.

DA LUZ, W. C.; MENDES, M. A. S.; FERREIRA, M. A. S. V.; and URBEN, A. F. (1993). Tilletia indica on wheat in the south of the state of Rio Grande do Sul, Brazil and measures for eradication. Fitopatologia Brasileira, 18, S329.

DURÁN, R. (1972). Further aspects of teliospore germination in North American smut fungi. II. Canadian Journal of Botany, 50, 2569-2573.

FUENTES-DÁVILA, G. (2007). Chemical control of karnal bunt by foliar applications. Phytopathology, 97(7), S37. Supplement.

FUENTES-DÁVILA, G.; AMMAR, K.; FIGUEROA-LÓPEZ, P.; CORTÉS-JIMÉNEZ, J. M.; FÉLIXVALENCIA, P.; FÉLIX-FUENTES, J. L.; CHÁVEZ-VILLALBA, G.; CAMACHO-CASAS, M. A.; y BORBÓN-GRACIA, A. (2012a). Reacción de líneas avanzadas de triticale al carbón parcial. Memorias del XIV Congreso Internacional/XXXIX Congreso Nacional de la Sociedad Mexicana de Fitopatología, A.C. Julio 22-26, 2012. Nuevo Vallarta, Nayarit, México. Resumen 140.

FUENTES-DÁVILA, G.; AMMAR, K.; FIGUEROA-LÓPEZ, P.; CORTÉS-JIMÉNEZ, J. M.; FÉLIXVALENCIA, P.; FÉLIX-FUENTES, J. L.; CHÁVEZ-VILLALBA, G.; CAMACHO-CASAS, M. A.; y BORBÓN-GRACIA, A. (2012b). Reacción de líneas avanzadas de triticale al carbón parcial durante el ciclo agrícola 2008-2009 en el Valle del Yaqui. p. 446. Memorias del XXIV Congreso Nacional y IV Internacional de Fitogenética. Septiembre 24 al 28, 2012. Monterrey, Nuevo León, México.

FUENTES-DÁVILA, G.; AMMAR, K.; FIGUEROA-LÓPEZ, P.; CORTÉS-JIMÉNEZ, J. M.; FÉLIXVALENCIA, P.; FÉLIX-FUENTES, J. L.; CHÁVEZ-VILLALBA, G.; CAMACHO-CASAS, M. A.; y BORBÓN-GRACIA, A. (2013a). Reacción de líneas avanzadas de triticale al carbón parcial. Memorias del XV Congreso Internacional/XL Congreso Nacional de la Sociedad Mexicana de Fitopatología, 
A.C. Julio 20-25, 2013. Huatulco, Oaxaca, México. Revista Mexicana de Fitopatología vol. 31, suplemento 2013. Resumen 53. p. S101. pp. 125.

FUENTES-DÁVILA, G.; AMMAR, K.; FIGUEROA-LÓPEZ, P.; CORTÉS-JIMÉNEZ, J. M.; FÉLIXVALENCIA, P.; CAMACHO-CASAS, M. A.; FÉLIX-FUENTES, J. L.; y CHÁVEZ-VILLALBA, G. (2014). Reacción de líneas avanzadas de triticale al carbón parcial (Tilletia indica) bajo inoculación artificial en campo. Memorias del XVI Congreso Internacional y XLI Congreso Nacional de la Sociedad Mexicana de Fitopatología, A.C. Julio 20-24, 2014, Ixtapan de la Sal, Edo. de México, México.

FUENTES-DÁVILA, G.; FÉlIX-VALENCIA, P.; AYÓN-IBARRA, C. A.; FIGUEROA-LÓPEZ, P.; CAMACHO-CASAS, M. A.; FÉLIX-FUENTES, J. L.; CHÁVEZ-VILLALBA, G.; and ROSASJÁUREGUI, I. A. (2016). Biological effectiveness of several fungicides for control of karnal bunt (Tilletia indica) of wheat, in the field. Annual Wheat Newsletter, 62, 28-31.

FUENTES, D. G.; FigueroA, L. P.; CORTÉS, J. J. M.; FÉliX, V. P.; CAMACHO, C. M. A.; CHÁVEZ, V. G.; FÉLIX, F. J. L.; y ORTIZ, A. A. A. (2013b). Evaluación de la reacción al carbón parcial de líneas avanzadas de triticale en el valle del Yaqui, Sonora, durante el ciclo agrícola 2010-11. Reuniones Nacionales de Investigación e Innovación Pecuaria, Agrícola, Forestal y Acuícola-Pesquera Veracruz 2013, XXVI Reunión Científica-Tecnológica, Forestal y Agropecuaria Veracruz 2013 / V Reunión de Investigación Agrícola, Pecuaria, Forestal y Acuícola en el Trópico Mexicano. Septiembre 10-13, 2013. Boca del Río, Veracruz, México. p. 220.

FUENTES-DÁVILA, G.; RAJARAM, S.; PFEIFFER, W. H.; ABDALLA, O.; VAN-GINKEL, M.; MUJEEB-KAZI, A.; y RODRÍGUEZ-RAMOS, R. (1993). Resultados de inoculaciones artificiales del 5o. vivero de selección para resistencia a Tilletia indica Mitra. Revista Mexicana de Micología, 9, 5765.

FUENTES-DÁVILA, G.; and RAJARAM, S. (1994). Sources of resistance to Tilletia indica in wheat. Crop Protection, 13, 20-24.

FUENTES-DÁVILA, G.; ROSAS-JÁUREGUI, I. A.; AYÓN-IBARRA, C. A.; ÁLVAREZ-AMADO, K. D.; FÉLIX-VALENCIA, P.; and FÉLIX-FUENTES, J. L. (2018). Biological effectiveness of Opus, Folicur, Juwel, and Bemistop for control of Karnal bunt (Tilletia indica) of wheat in the field. Annual Wheat Newsletter, 64, 30-33.

FUENTES-DÁVILA, G.; SINGH, R. P.; AYÓN-IBARRA, C. A.; ROSAS-JÁUREGUI, I. A.; FÉLIXVALENCIA, P.; CAMACHO-CASAS, M. A.; FÉLIX-FUENTES, J. L.; and CHÁVEZ-VILLALBA, G. (2017). Reaction of elite advanced bread wheat lines to karnal bunt under artificial field inoculation, during the 2014-15 crop season. Annual Wheat Newsletter, 63, 30-33.

FUENTES-DÁVILA, G.; TAPIA-RAMOS, E.; TOLEDO-MARTÍNEZ, J. A.; y FIGUEROA-LÓPEZ, P. (2005). Evaluación de efectividad biológica de folicur 250 EW (Tebuconazol) para el control del carbón parcial (Tilletia indica) del trigo (Triticum aestivum), en el valle del Yaqui, Sonora, México, durante el ciclo de cultivo 2003-2004. Resúmenes, XIII Congreso Latinoamericano de Fitopatología, III Taller de la Asociación Argentina de Fitopatólogos. 19-22 de Abril, 2005. Villa Carlos Paz, Córdoba, Argentina. Resumen HC-29, página 271. 640 p. 
METZGER, R. J. (1984). Screening for genetic resistance in the field. In: Karnal Bunt Disease of Wheat - Proceedings of a Conference, April 16-18, 1984, Ciudad Obregon, Sonora, Mexico. CIMMYT (Centro Internacional de Mejoramiento de Maiz y Trigo) pp. 15-17.

MITRA, M. (1931). A new bunt of wheat in India. Annals of Applied Biology, 18, 178-179.

MITRA, M. (1935). Stinking smut (bunt) of wheat with a special reference to Tilletia indica Mitra. Indian Journal of Agricultural Science, 5, 1-24.

MUNJAL, R. L. (1975). Status of Karnal bunt (Neovossia indica) of wheat in Northern India during 19681969 and 1969-1970. Indian Journal of Mycology and Plant Pathology, 5(2), 185-187.

SALAZAR-HUERTA, F. J.; FIGUEROA-LOPEZ, P.; SMILANICK, J. L.; and FUENTES-DÁVILA, G. (1997). Evaluation of foliar fungicides for control of Karnal bunt of wheat during 1986-1989 in northwestern Mexico. Revista Mexicana de Fitopatología, 15, 73-80.

SECRETARÍA DE AGRICULTURA Y RECURSOS HIDRÁULICOS (SARH). (1987). Cuarentena interior No. 16 contra el Carbón Parcial del trigo. Secretaría de Agricultura y Recursos Hidráulicos. Diario Oficial, (jueves) 12 de Marzo de 1987, México.

SINGH, D. V.; AGARWAL, R.; SHRESTHA, K. J.; THAPA, R. B.; and DUBIN, H. J. (1989). First report of Tilletia indica on wheat in Nepal. Plant Disease, 73, 273.

SINGH, D. V.; DHALIWAL, H. S.; and METZGER, R. J. (1988). Inoculum and time for screening against Karnal bunt disease of wheat. Indian Phytopathology, 41(4), 632-633.

SMILANICK, J. L.; HOFFMANN, J. A.; SECREST, L. R.; and WIESE, K. (1988). Evaluation of chemical and physical treatment to prevent germination of Tilletia indica teliospores. Plant Disease, 72, 46-51.

TORARBI, M.; MARDOUKHI, V.; and JALAIANI, N. (1996). First report on the occurrence of partial bunt on wheat in the southern parts of Iran. Seed and Plant, 12, 8-9.

ZADOKS, J. C.; CHANG, T. T.; and KONZAK, C. F. (1974). A decimal code for the growth stages of cereals. Weed Research, 14, 415-421. 